DISCUSSION AND CORRESPONDENCE.

THE USE OF THE WORD GEEST IN GEOLOGY.

To the Editor of Science: The American Geologist for December, 1902, reprints an extract from the 11th Annual Report U. S. Geological Survey, by W J McGee, upon the use of the term geest in geology. Dr. McGee calis attention to the fact that there is no general term in common use to designate the undisturbed products of weathering, and proposes the Dutch word geest, as used by $\mathrm{De}$ Luc, Eaton and Beck, to distinguish such material in situ from alluvium or tr.nsported material. Dr. McGee overlooks une fact that geest and alluvium are themselves specific terms denoting members of a class, while for the class itself a common descriptive or 'denotative' term is still wanting. In his first sentence he introduces his subject as ' the superficial mantle of rock débris.' Later it appears as ' the extensive mantle,' etc., and 'the unconsolidated materials by which these [solid] rocks are mantled.' Every recent writer upon geology and physical geography has had to wrestle with this problem and has usually solved it by some circumlocution. The older writers, Lyell, Dana, Prestwich, Geikie, Le Conte and even Scott use only the term soil, and appear to do so without any sense of unfitness or inadequacy. Brigham ('Text-book of Geology') discusses 'the whole sheet of crumbled rock material which mantles most of the rocky foundation of the lands,' but finds no better term for it than 'this mantle.' Elsewhere he uses 'rocky débris' and 'land waste.' Gilbert and Brigham ('Introduction to Physical Geography') use several variations of the theme, "earthy mantle that covers the rock,' 'waste cover,' ' earthy cover,' 'waste mantle.' They state explicitly: "The student should distinguish clearly and use it [soil] only of the veneer of earthy matter which is especially fitted to support life.' Davis ('Physical Geography') commonly uses waste with various modifiers, as 'rock waste,' 'land waste,' 'sheet of loosened rock waste,' 'cloak of rock waste,' 'waste sheet.' In the Journal of Geology, Vol. 10, p. 98 ff., he uses many times the phrases 'sheet of waste' and 'cloak of waste.'
Merrill ('Rocks, Rock Weathering and Soils') strikes out boldly and manufactures a new term, regolith, blanket rock for the 'entire mantle of unconsolidated material, whatever its nature or origin.' For nonclassical students I have translated regolith into mantle rock, and have used that term for several years with perfect satisfaction. The above quotations show how difficult it is to avoid some term expressive of the idea of a cover or mantle. Waste is open to the objection that it expresses a half truth in such a way as to give a false impression. It is waste only in relation to its past. In its destination and future functions it is not waste, but ' the dust of continents to be.' It is always a mantle which covers some other kind of rock, and in geography the distinction between the mantle and that which it covers is more important than the distinctions between aqueous, igneous and metamorphic rocks. I suggest, then, the term mantle rock for the material which Merrill has named the regolith, and hope that it may find favor and supply a long-felt want. It is plain Saxon, expresses the most. distinctive and striking character of the material, has no misleading implications and fits readily into any place where it is needed. I find in the note-books of my students such records as these: "Lawrence Co., bed-rock limestone, mantle red clay. Green Co., bed-rock shale, mantle glacial drift." To substitute waste, detritus, débris, geest, alluvium, unconsolidated materials, or any other term for mantle in these phrases would be distinctly no improvement.

Charles R. Dryer.

Terre Haute, Ind.

\section{ATAVIC MUTATION.}

To the Editor of Science: Dr. White's article on aggregative atavic mutation of the tomato, in ScIence for January 9 recalls to me a case of-apparently-similar atavic mutation, which Dr. White should be in a position to investigate, if, indeed, he has not already done so. When I lived in Washington, some ten years ago, we were rarely able to get any really sweet sweet corn, such as is so abundant here in New England. The 
vegetable commonly found in the market was as tasteless as white field corn. The market people told us that to obtain sweet corn, it was necessary to plant northern seed every time, while the seed corn grown from northern seed always gave the tasteless variety.

Since, I believe, our sweet varieties of corn are derived by cultivation from the white field corn, this looks very like a case of atavic mutation. I hope that Dr. White or some other investigators in Washington may be able to give us further information about this matter. JoHN MURDOCH.

Public Library, Boston, Mass., January 12, 1903.

\section{NOTES ON INORGANIC CHEMISTRY.}

DISCOVERY OF NEW PLATINUM DEPOSITS.

A New YoRK World dispatch from St. Petersburg of the date January 18 announces the discovery of vast deposits of platinum on the river Gusseva. It is said that within a month 25,000 men swarmed to the diggings, and before the police could reach the camp the miners got away with $\$ 1,500,000$ worth of platinum. The locality indicated in the dispatch is in the upper, or Goroblagodatsk district, on the eastern watershed of the Oural Mountains. The mines of this region are chiefly owned by Count Shouvalof and a number of companies. About eighty miles to the south is the Nizhni Tagilsk district, which is owned by the Demidoffs, and which has been the greatest producer of platinum in the past. The last few years the northern district has been a larger producer, but the sands and rock have run very low in platinum. While as recently as 1870 the richness of the sands was as high as one ounce to the ton, in 1895 the average was hardly one and a half pennyweights to the ton. The total production of that year was less than 150,000 ounces. If the figures of the World dispatch are reliable, it would indicate the production in a month of more than the usual annual output of late years. The platinum problem has become a very serious one, for while the demand has increased rapidly the last few years, the supply has been diminishing. Great efforts have been made to discover new fields, but without much practical success. Platinum occurs in many places, but generally in insufficient quantities to pay for working. The Goroblagodatsk district consists chiefly of the river Iss and its tributaries. The total length of these streams is about sixty miles, and the Gusseva is one of these aflluents. Allowing for all the probable exaggeration of the dispatch, it would seem that deposits have been discovered in this region which must be far richer than any which have been worked for many years. It is sincerely to be hoped that they shall prove to be of considerable area.

J. L. H.

\section{CURRENT NOTES ON METEOROLOGY.}

REPORT OF THE CHIEF OF THE WEATHER BUREAU.

The 'Report of the Chief of the Weather Bureau' for 1901-1902 (4to, pp. 342) contains a number of interesting facts regarding the work of the Bureau. The storm warnings issued for the transatlantic steamship routes were so successful that the secretary of 'Lloyd's,' in London, conveyed to the Chief of the Bureau the congratulations of his committee ' on the infallibility of the predictions that have been supplied by the forecasts.' On Augúst 1, 1902, 10,025 rural free maildelivery routes were in operation, serving approximately $1,000,000$ families. Of these families, 105,000 , served by about 1,000 routes, were furnished with the forecasts of the Weather Bureau. If the necessary funds were available, it would be possible to make the distribution of the daily forecasts coextensive with the rural free delivery itself. Professor Abbe has acted as the general adviser of the trustees of the Carnegie Institution on matters pertaining to meteorology, and has also been charged with the oversight of the aerial research work of the Weather Bureau. A valuable set of nephoscope observations from the West Indies has been secured, from May, 1899, to May, 1902. Among the special studies carried on by the Bureau are the following: Investigation of the intensity of solar radiation by means of Angström's electric compensation pyrheliometer; a new barometric 